\title{
Likelihood ratio test between two groups of castor oil plant traits
}

\section{Teste de razão de verossimilhança entre dois grupos de caracteres de mamoneira}

\author{
Betania Brum $^{\text {I* }}$ Sidinei José Lopes ${ }^{\text {II }}$ Daniel Furtado Ferreira ${ }^{\text {III }}$ \\ Lindolfo Storck ${ }^{I}$ Alberto Cargnelutti FilhoII
}

\section{ABSTRACT}

The likelihood ratio test (LRT), to the independence between two sets of variables, allows to identify whether there is a dependency relationship between them. The aim of this study was to calculate the type I error and power of the LRT for determining independence between two sets of variables under multivariate normal distributions in scenarios consisting of combinations of 16 sample sizes; 40 combinations of the number of variables of the two groups; and nine degrees of correlation between the variables (for the power). The rate of type I error and power were calculate at 640 and 5,760 scenarios, respectively. A performance evaluation of the LRT was conducted by computer simulation by the Monte Carlo method, using 2,000 simulations in each scenario. When the number of variables was large (24), the TRV controlled the rate of type I errors and showed high power in sizes greater than 100 samples. For small sample sizes (25, 30 and 50), the test showed good performance because the number of variables did not exceed 12.

Key words: Ricinus communis L., type I error, power test, multivariate normal distribution.

\section{RESUMO}

$O$ teste de razão de verossimilhança para a independência entre dois grupos de variáveis permite-nos identificar se existe uma relação de dependência entre eles. $O$ objetivo deste trabalho foi calcular o erro tipo I e o poder do teste de razão de verossimilhança para independência entre dois grupos de caracteres, com distribuição normal multivariada, em cenários constituídos pelas combinações de: 16 tamanhos de amostra; 40 combinações de número de caracteres dos dois grupos; e nove graus de correlação entre os caracteres (para o poder). A taxa de erro tipo I e o poder foram calculados em 640 e 5.760 cenários a taxa de erro tipo I e o poder, respectivamente. A avaliação do desempenho do teste de razão de verossimilhança foi realizada por meio de simulação computacional pelo método Monte Carlo, utilizando-se 2.000 simulações em cada um dos cenários. Quando o número de caracteres é grande (24), o teste de razão de verossimilhança controla a taxa de erro tipo I e apresenta poder elevado (próximo a 100\%), em tamanhos de amostra superiores a 100. Para tamanhos amostrais pequenos $(25,30$ e 50), o teste apresenta bom desempenho (erro tipo I esperado e poder elevado), desde que o número de caracteres não exceda a 12.

Palavras-chave: Ricinus communis L., Erro tipo I, Poder do teste, distribuição normal multivariada.

\section{INTRODUCTION}

Brazil, the largest producer of castor bean in the world in the 1970s, suffered a drastic reduction in the planted area due to production and marketing problems. Studies (BRUM et al., 2011; SANTOS et al., 2011; MESQUITA et al., 2012) have been conducted with the castor oil plant to increase yield because the production level of this crop has stagnated at $600 \mathrm{~kg}$ $\mathrm{ha}^{-1}$ since the $1990 \mathrm{~s}$. Records indicate a mean yield of $2,000 \mathrm{~kg} \mathrm{ha}^{-1}$ in India, the major producing country (SEVERINO, 2006).

An understanding of the linear associations between groups of seed, seedling, adult plant and produced bean variables allows the determination of the most important variables for the selection of plants to obtain a final product of high quality (BRUM et al., 2011). The association between groups of variables

IDepartamento de Ciências Agrárias, Universidade Tecnológica Federal do Paraná (UTFPR), 85503-390, Pato Branco, PR, Brasil. E-mail: bbufsm@gmail.com. "Corresponding author.

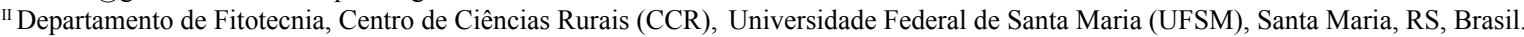
"IIUniversidade Federal de Lavras (UFLA), Lavras, MG, Brasil. 
can be rigorously evaluated by canonical correlation analysis (MINGOTI, 2007). There are studies that employ canonical correlation analysis in agricultural crops, such as pigeon pea (SANTOS et al., 1994), bean (COIMBRA et al., 2000), potato (RIGÃO et al., 2009), and castor bean (BRUM et al., 2011).

An important assumption to be tested for the use of canonical correlation is whether the measurement vectors of variables from two groups, $\mathrm{X}$ and $\mathrm{Y}$, are independent or uncorrelated; if they are, the canonical correlation analysis is no longer useful, as the correlation between all of the linear combinations will be equal to zero (CRUZ \& REGAZZI, 1997). The condition of independence between two sets of variables can be tested using the likelihood ratio test (LRT), i.e., if the covariances between the two groups are equal to zero (FERREIRA, 2008).

There is very little information available in the literature about the use of the LRT for determining the independence between two groups of variables. Thus, the objective of this study was to calculate the type I error and the power of the LRT for determining the independence between two groups of castor oil plant traits under a multivariate normal distribution in scenarios consisting of the combinations of 16 sample sizes; 40 combinations of the number of traits from the two groups; and nine degrees of correlation between the traits (for the power).

\section{MATERIALS AND METHODS}

The variable database of the castor oil plant hybrid Lyra, from which the means and variances were used to generate multivariate random samples, was obtained from the experiment by BRUM (2009). For this study, the adult plant and production variables were used (Table 1). The means and variances used to generate the covariance matrices and; therefore, the multivariate random samples for the calculations of the type I error and the power of the LRT for the independence between two groups of variables belong to the groups of adult plants and the production of the hybrid Lyra (Table 1).

To obtain the multivariate normal samples used in the calculations of the type I error rates of the LRT for the independence between two groups of variables under the null hypothesis, matrices with zero covariances and real variances and means were used. These were obtained from 14 adult plant variables (Group I) and from 10 bean production variables (Group II) of the castor oil plant hybrid Lyra.

The matrices were obtained by the combination of variables from the two groups (14 from adult plants and 10 from bean production), beginning with the combination $3+3$ (3 variables from Group I and 3 variables from Group II), then $3+4$ ( 3 variables from Group I and 4 variables from Group II) up to the $14+10$ combination (14 variables from Group I and 10 variables from Group II), totaling 40 combinations.

Hypotheses that were established in the LRT for the independence between two groups of variables were $\mathrm{H}_{0}: \sum_{\mathrm{xy}}=0_{\mathrm{p}+\mathrm{q}}$ (the two groups of variables are independent) and $\mathrm{H}_{1}: \sum_{\mathrm{xy}} \neq 0_{\mathrm{p}+\mathrm{q}}$ (the two groups of variables are not independent), where $0_{p+q}$ is the zero matrix.

The chi-squared statistic of the LRT for the independence between two groups of variables that was used was that corrected by Bartlett (JOHNSON \& WICHERN, 2007; MINGOTI, 2007; FERREIRA, 2008). In this test, the value of the statistic calculated was compared to the tabulated critical value of the chi-squared distribution (upper 5\% quantile), with $\mathrm{p} \times \mathrm{q}$ degrees of freedom at $5 \%$ level of significance; when the calculated value is greater than the tabulated value, the null hypothesis is rejected, and it is concluded that the two groups considered in the study are not independent.

To calculate the probability of making a type I error in the LRT for the independence between two groups of variables, a computational simulation by the Monte Carlo method was performed, considering the following scenarios: 16 sample sizes - 25, 30, 50, 100, 200, 300, 400, 500, 600, $750,1,000,1,500,2,000,3,000,4,000$ and 5,000; 40 combinations of the number of variables between the two groups - starting with $3+3,3+4,3+5,3+6,3+7$, $3+8,3+9,3+10,4+4,4+5,4+6,4+7,4+8,4+9,4+10$, and $5+3$ up to $14+10$; and a degree of correlation between the variables of the covariance matrices: $\sum_{\mathrm{XY}}=0$; totaling 640 scenarios $(16 \times 40 \times 1)$. For each scenario, 2,000 simulations with multivariate normal distribution were performed, which resulted in $1,280,000$ simulations $(640 \times 2,000)$. In each simulation, the calculated chi-squared values and the p-value of the LRT for the independence between two groups of variables were obtained. The type I error rate was calculated as the ratio between the number of times the null hypothesis was rejected ( $p$-value $\leq 0.05$ ) and the total number of simulations, 2,000.

To test if the type I error rates differed from the significance level adopted $(\alpha=1 \%)$, the lower limit $(3.475 \%)$ and the upper limit $(6.255 \%)$ of the exact confidence interval (CI) of $99 \%$ were used for a proportion $\hat{p}=0.05$, which was calculated as $C I=\hat{p} \pm Z_{\alpha / 2} \sqrt{\frac{\hat{p}(1-\hat{p})}{n}}$, where $\mathrm{n}=2,000$ simulations 
Table 1 - Variance and mean of the castor bean adult plant and production variables in 50 Lyra hybrid plants.

\begin{tabular}{|c|c|c|}
\hline Traits (unit of measure) & Variance & Mean \\
\hline 1. Days to flowering (days) & 40.328 & 48.720 \\
\hline 2. Degrees-day to flowering $\left({ }^{\circ} \mathrm{C}\right.$ day) & 7134.138 & 578.434 \\
\hline 3. Height of the plant at the start of flowering $(\mathrm{cm})$ & 16.436 & 25.610 \\
\hline 4. Length of the stem with real leaves $(\mathrm{cm})$ & 12.698 & 17.890 \\
\hline 5. Diameter of the stem $10 \mathrm{~cm}$ from the ground $(\mathrm{cm})$ & 9.740 & 19.786 \\
\hline 6. Number of leaves per plant & 1.349 & 9.280 \\
\hline 7. Leaf area - length and width $\left(\mathrm{cm}^{2}\right)$ & 14920.2997 & 439.594 \\
\hline 8. Leaf area - length of the midrib $\left(\mathrm{cm}^{2}\right)$ & 13579.682 & 351.630 \\
\hline 9. Insertion height of the first raceme $(\mathrm{cm})$ & 16.437 & 25.610 \\
\hline 10. Days to the end of flowering from emergence (days) & 209.732 & 98.680 \\
\hline 11. Days to the end of flowering from sowing (days) & 179.488 & 109.068 \\
\hline 12. Height of the highest raceme $(\mathrm{cm})$ & 579.602 & 133.856 \\
\hline 13. Degrees-day to the end of flowering $\left({ }^{\circ} \mathrm{C}\right.$ day) & 38673.9307 & 1628.0140 \\
\hline 14. Number of inflorescences & 72.460 & 10.534 \\
\hline 1. Mean length of the racemes $(\mathrm{cm})$ & 89.746 & 31.426 \\
\hline 2. Number of racemes per plant & 54.790 & 9.160 \\
\hline 3. Mean number of capsules per raceme & 160.042 & 40.437 \\
\hline 4. Mean weight of capsules per raceme (g) & 938.800 & 77.906 \\
\hline 5. Total weight of capsules per plant (g) & 86702.219 & 648.691 \\
\hline 6. Mean weight of beans per raceme (g) & 820.594 & 64.343 \\
\hline 7. Weight of beans per plant (g) & 43732.589 & 462.721 \\
\hline 8. Peel $(g)$ & 9858.849 & 186.805 \\
\hline 9. Peel percentage $(\%)$ & 31.216 & 28.352 \\
\hline 10. Weight of 100 beans (g) & 17.900 & 51.085 \\
\hline
\end{tabular}

and $Z_{a / 2}=2.575829304$, obtained from the standard normal with mean zero and standard deviation of one. Therefore, only type I error rates outside of this interval $(3.475 \%$ to $6.255 \%)$ were considered different from the nominal significance value of $5 \%$.

To obtain the multivariate normal samples used in the power calculations of the LRT for the independence between two groups of variables, the same variances and vector of means as in the calculation of the type I error rates (Table 1) and covariances given by $\sum_{x y}=s_{i} \times s_{y} \times \rho$, in which $S_{i}$ is the standard deviation of the $\mathrm{i}^{\text {th }}$ variable; $S_{\mathrm{j}}$ is the standard deviation of the $j^{\text {th }}$ variable, $i=1,2, \ldots, p$ and $\mathrm{j} 1,2, \ldots, \mathrm{q}$; and $\mathrm{r}$ is the Pearson correlation coefficient between the variables $\mathrm{i}$ and $\mathrm{j}$ (evaluated degrees of correlation: $\mathrm{r}=0.1,0.2,0.3,0.4,0.5,0.6,0.7,0.8$ and 0.9 ), were used. Therefore, the total number of matrices generated for the power calculation was 360 (40 combinations of variables $\times 9$ degrees of correlation). Vectors of the means of groups $1\left(\mu_{\mathrm{x}}\right)$ and $2\left(\mu_{\mathrm{Y}}\right)$ were the same used to generate multivariate random samples in the calculation of the type I error rates, without loss of generality.

Regarding the application of the test for the power calculation, the only difference in relation to the procedure applied to calculate the type I error rates was that the LRT for the independence between two groups of variables was constructed under the alternative hypothesis, i.e., covariance matrices exhibited correlation between the variables $(\mathrm{r}=0.1$ to 0.9 ). In other words, multivariate normal random samples were generated to assess the power of the test to reject the $\mathrm{H}_{0}$, which is false by construction.

In the Monte Carlo simulation for the power calculations, the following scenarios were considered: 16 sample sizes $-25,30,50,100,200,300$, $400,500,600,750,1,000,1,500,2,000,3,000,4,000$ and 5,000; 40 combinations of variables between the 
two groups - starting with $3+3,3+4,3+5,3+6,3+7$, $3+8,3+9,3+10,4+4$ up to $14+10$; and nine degrees of correlation between the variables $(\mathrm{r}=0.1,0.2,0.3,0.4$, $0.5,0.6,0.7,0.8$ and 0.9$)$, totaling 5,760 scenarios (16 $\times 40 \times 9)$ and $11,520,000$ simulations $(5,760 \times 2,000)$. In each scenario, the power was calculated by the ratio between the number of times the null hypothesis was rejected and the total number of simulations $(2,000)$, considering a significance level of $5 \%$.

Simulations were performed with the use of the Monte Carlo method, and the calculations of the type I error rates and the power were conducted by means of a program developed in the $\mathrm{R}$ environment for Windows, version 2.13.0 (R DEVELOPMENT CORE TEAM, 2010). Multivariate normal samples were obtained in $\mathrm{R}$ with the use of the mvrnorm function from the MASS package. To confirm the normality (multivariate normal distribution) of the multivariate random samples generated, the mvShapiro test function $(\alpha=5 \%)$ of the mvShapiro test package of the R software was used (VILLASENOR ALVA \& ESTRADA, 2009).

\section{RESULTS AND DISCUSSION}

Values of the type I error rates of the LRT for the independence between two groups of variables under multivariate normal distribution in small sample sizes, $n=25$, (Figure 1A) increased significantly with the increase in the number of variables. With $n=50$, the values of the type I error tended to stabilize, even when the number of variables was increased (Figure 1A).

In both situations ( $\mathrm{n}=25$ and 50$)$, the effect on the type I error rates was primarily due to the total number of variables used in the two groups of variables and not to the number of variables in each group because different combinations of the number of variables in each group generated similar type I error results (repeated points for the same $p$ in figure 1 A and B). In sample sizes of 100 and 500 observations (Figure 1B), all of the type I error rates stayed within the $99 \%$ confidence interval, regardless of the number of variables. In sample sizes greater than 500, the same result was observed (data not shown).

The minimum level of significance of $5 \%$ of the LRT for the independence between two groups of variables was not violated in the sample size $n=25$ when the number of variables in the study was at most 12 (Figures 1A). However, with 14 or more variables, the type I error rates increased, and the test became liberal (it exceeded the upper limit of $99 \%$ of the $\mathrm{CI}=6.255 \%$ ). A hypothesis test is classified as liberal when the type I error rates are higher than the minimum significance level that is established $(\alpha)$ (SILVA et al., 2008). With samples larger than $n=50$ (Figure 1B), increases in the total number of variables did not affect the type I error rate, and it stayed close to $5 \%$. In this case, the type I error rates exceeded the upper limit of $99 \%$ of the CI only with $n=22,23$ and 24 variables.

When evaluating the behavior of two tests for the equality of variance matrices of $\mathrm{k}$ populations (multivariate Bartlett test and its bootstrap version) with the use of a Monte Carlo simulation, in normal and non-normal populations, in combinations of the sample sizes (n), number of variables (p), correlations (r) and number of populations (k), SILVA et al. (2008) reported that the multivariate Bartlett test controls the type I error in almost all combinations for $\mathrm{k}=2$; however, it becomes liberal when $\mathrm{k}$ is increased to 5 . In both situations $(\mathrm{k}=2$ and 5$)$, the type I error rates increased greatly with the increase in the number of variables in sample sizes varying from 5 to 50 . These results corroborate those observed in this study.

Studying various tests for covariance matrices in samples with $\mathrm{P}=2,3$ and 5 variables in different matrix structures (modification in the variance, in the correlation, and in both), including the LRT, to test the hypothesis that the covariance matrix of a process $\left(\sum\right)$ is equal to a particular matrix $\left(\sum_{0}\right)$, PINTO (2009) reported that the LRT approximated by the chi-squared distribution does not control type I errors for samples of size $n=10$ in bivariate situations and for samples of sizes $n=10$ and 25 in situations with $\mathrm{P}=3$ and 5 variables. Thus, the study concluded that the LRT is not a good test for studies involving a small number of samples. This result, as well as those observed in this study, indicate that LRTs for covariance matrices approximated by the chi-squared distribution do not control type I error in situations with small sample sizes combined with an increase in the number of variables.

Considering only type I errors, the recommendation is that when working with small sample sizes $(n \leq 30), 12$ variables at most should be used; for $n=50,18$ variables at most should be used. In sample sizes greater than 100, any number of variables can be adopted within the interval studied ( $\mathrm{P}=6$ to 24 variables).

The power of the LRT for the independence between two groups of variables is small when the sample size is 25 elements, which is associated with the low correlation $(\mathrm{r}=0.1)$ between the variables (Figure 1C). Considering $\mathrm{n}=25$ and $\mathrm{r}=0.1$ when using 24 variables, there is a marked increase in the power of the test, which reaches approximately $90 \%$. 


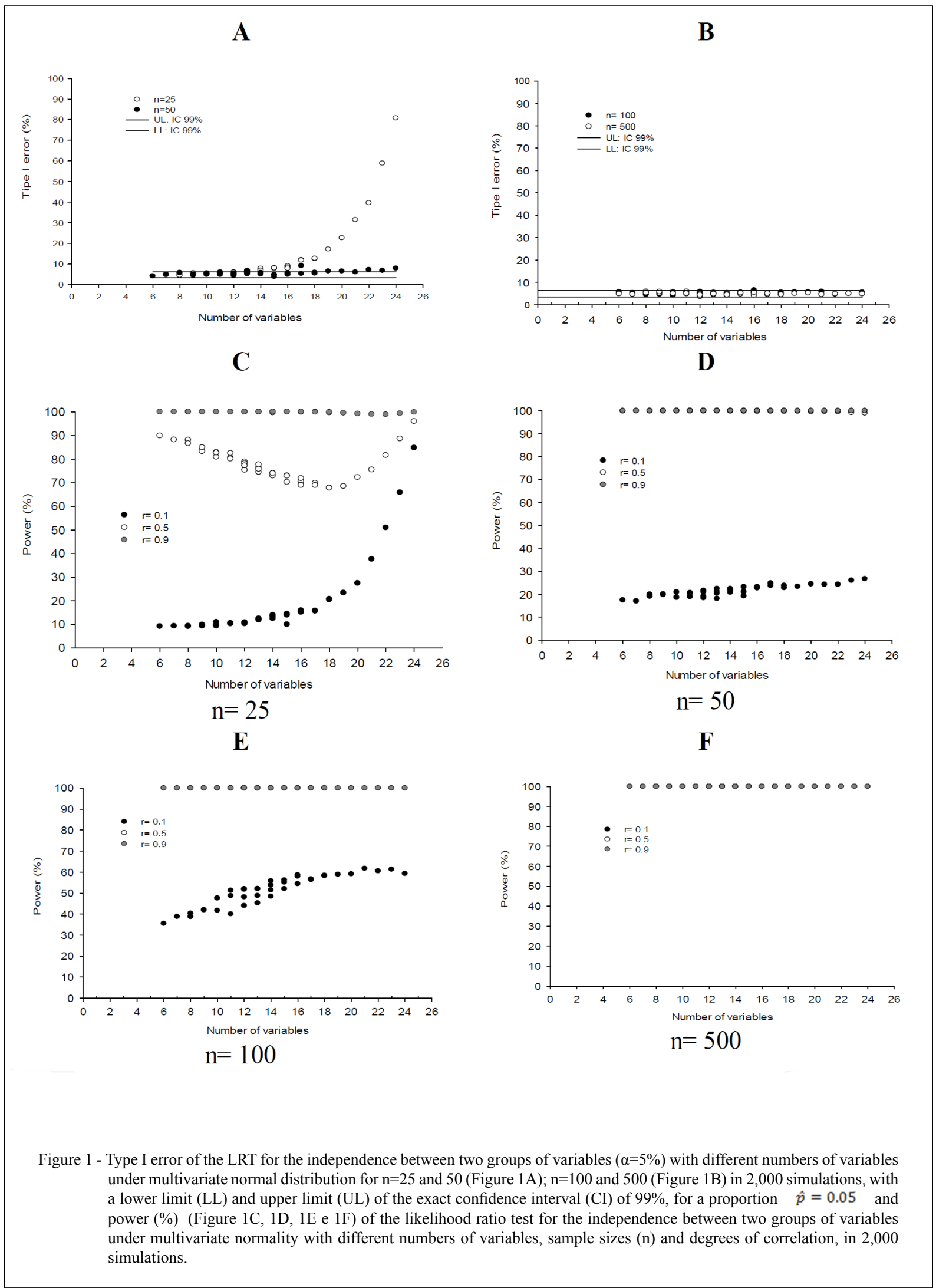

Ciência Rural, v.46, n.7, jul, 2016. 
Keeping $\mathrm{P}$ and $\mathrm{n}$ fixed and increasing the correlation, an increase in the values of power is observed in both cases, as expected; when the correlation is increased, the probability of rejecting $\mathrm{H}_{0}$ increases when it is, in fact, false (Figure 1C, 1D and 1E).

This observation indicates that the LRT for the independence between two groups of variables is efficient in the detection of small changes $(r=0.1)$ in the degree of correlation of the covariance matrices of the two groups of variables, which decreases the probability of making a type II error.

In the same way as observed for type I errors, the sample sizes affect the power of the test. In the situations with sample sizes $n=25$ and 50 and weak correlation $(\mathrm{r}=0.1)$, the power values are significantly lower (Figure 1C, 1D and 1E), regardless of the number of variables; in these situations, the type I error values were generally high (Figure 1A). PINTO (2009) observed that for $\mathrm{H}_{1}$ close to $\mathrm{H}_{0}$ (as is the case with $\mathrm{r}=0.1$ in this study), several tests of covariance matrices, including the LRT, are less powerful in small samples $(n=10)$ and that the power of the tests increases with an increase in the sample size. RIBEIRO (2010) concluded that in general, when increasing the sample size, the power of the tests increases. Furthermore, the author notes that the good behavior presented by the LRT and by the test proposed by SULLIVAN et al. (2007) for autocorrelated data corroborate the data presented by Pinto (2009), who states that these are the best tests for independent data.

Starting at $n=500$, all of the scenarios (including the lowest correlation, $\mathrm{r}=0.1$ ) reach power values of $100 \%$ (Figure 1D). This observation indicates that with the LRT, the use of very large samples may lead the researcher to incorrect decisions. By having a covariance matrix whose degree of correlation is low $(\mathrm{r}=0.1)$, the test will reject the $\mathrm{H}_{0}$, indicating that there is no independence between the two groups of variables (the groups are correlated); in fact, that decision (rejecting $\mathrm{H}_{0}$ ) was caused by the large sample size. Therefore, in situations in which $\mathrm{n}$ is large, the significance results of the hypotheses tests should be interpreted considering the practical significance because large samples can make the statistic tests very sensitive. This means that even very small effects without practical importance will be statistically significant (HAIR et al., 2009).

In evaluating the quality of fit of models of structural equations, HAIR et al. (2009) state that this effect is due to the sensitivity of the chisquared statistic of the LRT to the sample size, especially when the sample size is greater than 200 observations; when $\mathrm{n}$ is less than or equal to 100 , the chi-squared test will exhibit an acceptable fit (the differences are not significant between the estimated and observed covariance matrices), even when the model relationships are not significant. The authors concluded that because of this, the use of the chisquared test in structural equations will only be reliable within the sample size interval from 100 to 200 observations.

It was observed that there is a strong influence of the number of variables and the degree of correlation on the power values. With $P \geq 10$ variables and $r \geq 0.2$ (data not shown), high power values can already be observed when $n \geq 100$. In medium to high correlations $(\mathrm{r}=0.5$ to 0.9$)$ (CARVALHO et al., 2004), the power values are close to $100 \%$ even in the smaller sample sizes and in the lowest number of variables considered (six) (Figures 1C, 1D, 1E and 1F).

Similar results were reported by PINTO (2009), who observed that the power values of the LRT (for a specific covariance) with exact distribution and of the LRT with approximate chi-squared distribution were similar when the sample size was increased to 50 and 100 observations. However, the correlation or proximity between the power values of the test statistics in that case occurred in sample sizes lower than those observed in this study ( $\mathrm{n} \geq$ 500) of the LRT for the independence between two groups of variables.

Situations in which there are simultaneously higher, type I error and power characterizing a liberal test. In these cases, the high power values cannot be considered real (CANTELMO \& FERREIRA, 2007). When assessing the performance of the multivariate Shapiro-Wilk normality test, the authors report such a situation in which the test exhibited type I error values that were always high and close to $100 \%$ when increasing the number of variables to a certain fixed sample size (n varied from 10 to 200) while the power values were close to $100 \%$ in any situation.

\section{CONCLUSION}

Under multivariate normal distributions, for the LRT for the independence between two groups of variables to be robust, the following situations should be considered: i. type I errors are controlled up to $\mathrm{P}=12$ variables, even in small sample sizes ( $n=25$ and 30); in this situation, the power is low. For $\mathrm{n} \geq 100$ and $\mathrm{r} \geq 0.2$, the power values are high. When $n$ is small and the number of variables is increased, the power and type I error values increase; and ii. with 
the maximum number of variables $(\mathrm{P}=24)$, starting at $\mathrm{n} \geq 500$, increasing $\mathrm{p}$ did not cause significant changes in the type I error rates, which are kept close to $5 \%$, while the power increases in this situation.

\section{ACKNOWLEDGEMENTS}

To the Conselho Nacional de Desenvolvimento Científico e Tecnológico (CNPq) for the Doctoral, Post-Doctoral and Productivity in Research Scholarships.

\section{REFERENCES}

BRUM, B. Relações entre variáveis de: sementes, plântulas, plantas, produção e óleo em mamoneira. 2009. 120f. Dissertação (Mestrado em Agronomia) - Programa de Pós-Graduação em Agronomia, Universidade Federal de Santa Maria, RS.

BRUM, B. et al. Correlações canônicas entre variáveis de semente, plântula, planta e produção de grãos em mamoneira. Ciência Rural, v.41, n.3, p.404-411, 2011. Available from: $<$ http://www.scielo.br/scielo.php?script=sci arttext\&pid $=$ S0103-84782011000300007\&lng $=$ en \&nrm $=$ iso $>$. ISSN 0103-8478. Accessed: Jan. 15, 2014. doi: 10.1590/ S010384782011000300007 .

CANTELMO, N.F.; FERREIRA, D.F. Desempenho de testes de normalidade multivariados avaliados por simulação Monte Carlo. Ciência e Agrotecnologia, v.31, n.6, p.16301636, 2007. Available from: <http://www.scielo.br/scielo. php? script $=$ sci_arttext\&pid=S1413-70542007000600005\&lng =pt\&nrm=iso $>$. Accessed: Ago. 11, 2014. doi: 10.1590/S141370542007000600005 .

CARVALHO, F.I.F. et al. Estimativas e implicações da correlação no melhoramento vegetal. Pelotas: UFPel, 2004. 142p.

COIMBRA, J.L. M. et al. Correlações canônicas: II - análise do rendimento de grãos de feijão e seus componentes. Ciência Rural, v.30, n.1, p.347-352, 2000. Available from <http:// www.scielo.br/scielo.php?script $=$ sci_arttext\&pid $=\mathrm{S} 0103$ $84782000000100005 \& \operatorname{lng}=$ en\&nrm=iso $>$. Accessed: Mar. 15 , 2014. doi:10.1590/S0103-84782000000100005.

CRUZ, C.D., REGAZZI, A.J. Modelos biométricos aplicados ao melhoramento genético. 2.ed. Viçosa: UFV, 1997. 390p.

FERREIRA, D.F. Estatística multivariada. Lavras: UFLA, 2008. V.1. 662p.

HAIR, J.F. et al. Análise multivariada de dados. 6.ed. Porto Alegre: Bookman, 2009. 595p.

JOHNSON, R.A; WICHERN, D.W. Applied multivariate statistical analysis. 6.ed. New Jersey: Prentice Hall, 2007. 800p.

MESQUITA, E.F. et al. Crescimento e produção de duas cultivares de mamoneira sob fertilização NPK. Revista Caatinga, v.25, p.35-43, 2012. Available from: <http://periodicos.ufersa.edu.br/ revistas/index.php/sistema/article/viewFile/2140/pdf $>$. Accessed: Mar. 18, 2014.
MINGOTI, S.A. Análise de dados através de métodos de estatística multivariada: uma abordagem aplicada. Belo Horizonte: UFMG, 2007. 297p.

PINTO, L. P. Estudo comparativo de testes de hipótese multivariados para matrizes de covariâncias via simulação de Monte Carlo e suas aplicações em Controle de Qualidade. 2009. 109f. Dissertação (Mestrado em Estatística) - Programa de Pós-Graduação em Estatística, Universidade Federal de Minas Gerais, Belo Horizonte, MG.

R DEVELOPMENT CORE TEAM. R: A language and environment for statistical computing. Vienna, Austria, 2010. Available from: $<$ http://www.Rproject.org >. Accessed: Apr. 19, 2014.

RIBEIRO, R. L. F. Testes de hipótese multivariados para matrizes de covariâncias em processos autocorrelacionados com aplicações em controle de qualidade. 2010. $138 \mathrm{f}$. Dissertação (Mestrado em Estatística) - Programa de PósGraduação em Estatística, Universidade Federal de Minas Gerais, Belo Horizonte, MG.

RIGÃO, M.H. et al. Correlação canônica entre caracteres de tubérculos para seleção precoce de clones de batata. Ciencia Rural, v.39, n.8, p.2347-2353, 2009. Available from <http:// www.scielo.br/scielo.php? script $=$ sci arttext\&pid $=$ S010384782009000800012\&lng=en $\& n r m=$ iso $>$. Accessed: Feb. 12, 2014. doi: 10.1590/S0103-84782009005000190.

SANTOS, C.A.F. et al. Correlações canônicas entre componentes primários e secundários na produção de grãos em Guandu (Cajanus cajan (L.) Millsp). Revista Ceres, v.41, n.236, p.456-464, 1994. Available from: <http://www.ceres.ufv.br/ojs/index.php/ ceres/ article/view/2096>. Accessed: Mar. 20, 2014.

SANTOS, V. M. et al. Avaliação do crescimento e da produtividade da mamoneira BRS 149, Nordestina em dois níveis tecnológicos. Journal of Biotechnology and Biodiversity, v.2, p.58-66, 2011. Available from: <http://revista.uft.edu.br/index.php/JBB/article/ view/250>. Accessed: Apr. 15, 2014.

SEVERINO, S.L. Como a Índia tornou-se líder mundial na produção de mamona, 2006. Available from: < http://www. biodieselbr.com/colunistas/liv/india-lider-mundial-producaomamona.htm>. Accessed: Sept. 20, 2014.

SILVA, R.B.V. et al. Robustness of asymptotic and bootstrap tests for multivariate homogeneity of covariance matrices. Ciência e Agrotecnologia, v.32, n.1, p.157-161, 2008. Available from $<$ http://www.scielo.br/scielo.php?script $=$ sci arttext\&pid $=$ S141370542008000100023\&lng=en\&nrm=iso $>$. Accessed: Mar. 15, 2014. doi: 10.1590/S1413-70542008000100023.

SULLIVAN, J.H. et al. Step-down analysis for change in the covariance matrix and other parameters, Journal of Quality Technology, v.39, n.1, p.66-84, 2007. Available from: <http://connection.ebscohost. $\mathrm{com} / \mathrm{c} /$ articles/23550322/step-down-analysis-changes-covariancematrix-other-parameters $>$. Accessed: Jan. 15, 2014.

VILLASENOR ALVA, J.A.; ESTRADA, E.G. A Generalization of Shapiro-Wilk's test for multivariate normality preview. Communications in Statistics - Theory and Methods, v.38, n.11, p.1870-1883, 2009. Available from: <file://C:/Users/Win\%207/ Downloads/Alva.pdf $>$. Accessed: Jan. 15, 2014. 